\title{
Scientific Analysis of a Preserved Head of Hair at Romsey Abbey, UK
}

\author{
Jamie Cameron $^{\mathrm{a}^{*}}$, Thibaut Devièse ${ }^{\mathrm{a}}$, Francis Green ${ }^{\mathrm{b}}$ \\ ${ }^{a}$ Research Laboratory for Archaeology and the History of Art, University of Oxford, Dyson \\ Perrins Building, South Parks Road, Oxford, OX1 3QY, UK. \\ ${ }^{b}$ New Forest National Park Authority, Lymington Town Hall, Avenue Road, Lymington, \\ SO41 9ZG, UK.
}

5

*Corresponding author $<$ jamie.cameron@oii.ox.ac.uk $>$. Present address: Oxford Internet Institute, University of Oxford, 1 St Giles, Oxford, OX1 3JS, UK.

T. Devièse < thibaut.deviese@,rlaha.ox.ac.uk $>$

F. Green < frank.green@newforestnpa.gov.uk $>$

15

\section{Keywords}

Romsey Abbey, Saxon, hair, radiocarbon dating, isotope measurement, residue analysis

\section{Highlights}

- A preserved head of hair discovered in 1839 has been scientifically analysed.

- The hair has been radiocarbon dated to 895-1123calAD (95.4\% probability).

- The supporting wooden 'pillow' dates to 895-1016calAD (95.4\% probability).

- Isotopic analysis indicates a significant proportion of dietary marine protein.

- Molecular analysis has revealed the presence of Pinacea resin applied to the hair.

\begin{abstract}
This paper presents the results of a scientific investigation on a preserved head of hair, discovered in 1839 inside a lead coffin beneath the Norman Abbey of Romsey (Hampshire, UK). Accelerator mass

30 spectrometry (AMS) radiocarbon dating, modelled to account for dietary marine protein intake indicated by stable isotope analysis $\left(\delta^{13} C\right.$ and $\left.\delta^{15} N\right)$, suggests that this individual died between 895 1123 calAD (95.4\% probability). A wooden 'pillow' found supporting the hair produced a date of 895 1016 calAD (95.4\% probability). These results suggest that this burial dates from the end of the ninth century to the early twelfth century, placing it in the late Saxon or immediately post-Conquest era.

35 Analysis by gas chromatography/mass spectrometry (GC/MS) of residue adhering to the hair surface indicates the presence of Pinacea resin, deriving either from funerary ritual or hair care during life.
\end{abstract}

\section{Introduction}

The original date of foundation of Romsey Abbey is traditionally given as c.907 AD by Edward the Elder (Coldicott, 1989), although the exact date is debated (Collier, 1990). The present Abbey church dates largely to the Norman period. Excavations have revealed a smaller late Saxon stone abbey beneath the present construction, in

45 addition to a number of earlier phases of occupation dating from the middle to late Saxon era (Scott, 1996). 
A head of human hair is displayed in the Abbey (Figure 1). According to archival records, the remains were discovered by gravediggers in October 1839, underneath the west end of the south nave aisle (Major, 1862; Scott, 1996). An account written by the Churchwarden at the time, William Jenvey, describes the event (Hallett, 2015):

"We came about five feet below the pavement in contact with a leaden coffin, deposited in the earth, but without inscription of any kind. It was not of the shape now in use, but eighteen inches wide at the head, and tapered gradually down towards the feet, the width of which was thirteen inches only. The extreme length was five feet and the depth one foot three inches. It was made of very thick lead, and might possibly weigh nearly two hundred weight - the metal being about ten pounds to the square foot. The coffin was put together in a very substantial manner, the seams being folded over each other and welded: it was probably constructed before the use of solder was known. From lying so long in the earth, the lid was much decayed and bore a strong resemblance to the original lead ore... No bones whatever, either entire or broken were found within; but there had been preserved an oak shell, which was quite decayed, and mouldered into dust when exposed to the air. On removing the lid, a beautiful head of hair, with a tail plaited about eighteen inches long, evidently that of a young female, was discovered. The hair was lying on a block of oak, cut out hollow on purpose to receive the head of the corpse, when deposited within its narrow abode. The hair was in perfect form and appeared as though the skull had only been recently removed from it. The coffin is preserved in a safe and conspicuous place in the church (the apsis at the eastern extremity of the south aisle), and the hair is in a portable glass case, and lies on the same block of oak which has been its pillow for centuries".

70 Details of the discovery were published a year after the find in The Gentleman's Magazine (August 1840), along with an illustration of the hair and the lead coffin. The article records that, by this time, the inner wooden lining had already been cut up and distributed as souvenirs. At a later stage, the lead coffin was also lost (Walker, 2013). A later account written by the sexton, John Major, describes how the workers excavated through $5 \mathrm{ft}$ of concrete and $1.5 \mathrm{ft}$ of gravel, whereupon they uncovered the coffin. The Vicar was consulted and it was decided to ascertain whether any remains lay within it (Major, 1862):

“...making a hole on the Top...I Thrusted my hand to the head of the coffin to Find the scull. I found no bones but a scalp of Feameal haire as Bright as any Living Ladies haire I ever seen. there was 1 Finger Bone. it became dust immeadiately the aire came to it. The coffin was mad of verry curius workmanship the Sides was welted togeather the Top shut on the same as a Bandbox"

The Reverend Edward Berthon, Vicar of Romsey from 1860-1892, later described in his memoirs that the hair was presented by Mr Major to his predecessor, the Reverend Vaux, who threw the remains away (Berthon, 1899: 155):

“...the men came upon a very ancient coffin of lead, roughly hammered into shape. In this rude receptacle was found the most perfect and exquisitely beautiful chevelure of a young girl, the lovely auburn hair in wavy masses in front, and a perfect plait behind, as glossy as it had been in life. Major took it to the vicar, who threw it into the coal-hole, from whence the former rescued it, and had it enclosed in a glass case; but it was too late, the mischief was done, and its beauty gone for ever. The curious coffin was sold for old lead. Now, when did this girl live, and die? Nothing but dust remained of bones or clothing, only a block of oak for the head to rest on, and the coffin was lying north and 

ceased A.D. 426."

Reports from excavations carried out at the Abbey from 1973-1991 suggest that, if the recorded location and depth are accurate, then this burial may have pre-dated the late

100 Saxon Abbey that lies beneath the present Norman building, and may perhaps be contemporary with additional graves excavated in 1975 near to the north-west corner of the subsequently constructed late Saxon Abbey (Scott, 1996).

\section{Analytical Strategy}

Despite estimates of a mid-late Saxon date for this burial based on its recorded archaeological context (Green, pers. comm.), there have remained several unanswered questions regarding this intriguing survival.

- Firstly, the time period to which this burial dated was not known with any certainty.

- Secondly, nothing was known of the likely diet this individual consumed, which could indicate whether they were a lay person or an ecclesiastical figure.

- Thirdly, the identity of a black substance adhering to the hair was not known.

This new investigation will use AMS radiocarbon dating (Bronk Ramsey, 2008; Wood, 2015) to identify the age of the surviving hair and the wooden block on which 120 it rested.

Analysis of stable isotopes of carbon and nitrogen preserved in the hair keratin will also be undertaken in order to inform the calibration of the radiocarbon date, thus providing an insight into the likely diet of the deceased. This is a widely used 125 technique for the investigation of palaeodiet in archaeology (Lee-Thorp, 2008). The carbon isotopic ratios $\left(\delta^{13} \mathrm{C}\right)$ of tissues can provide insights into the types of plants consumed directly by the organism studied and/or through the organisms they consume, using knowledge of the isotopic fractionation of carbon involved in different photosynthetic pathways (O’Leary, 1988). Nitrogen isotopic ratios $\left(\delta^{15} \mathrm{~N}\right)$

130 can be used to study the position of an organism in the food chain, since increasing trophic level leads to enrichment in ${ }^{15} \mathrm{~N}$ (Bocherens and Drucker, 2003; Hedges and Reynard, 2007).

Another area of interest is the nature of the dark residue adhering to the hair. 135 Chemical characterisation of this residue using Gas Chromatography/Mass Spectrometry (GC/MS) will be performed to possibly provide insights into funerary ritual, treatment of hair during life, and perhaps even the history of the hair since its discovery. 
140 A summary of the analyses performed in this study is shown in Table 1.

\section{Materials and Methods}

\subsection{Materials}

145

\subsubsection{Archaeological artifact}

The head of hair has maintained the shape of the head, perhaps in part due to the survival of fragile areas of scalp. There is long and well-preserved ponytail, which remains plaited. The hair was found resting on a rectangular wooden block, upon which it is still displayed in a wooden box at the West End of the building (Figure 1).

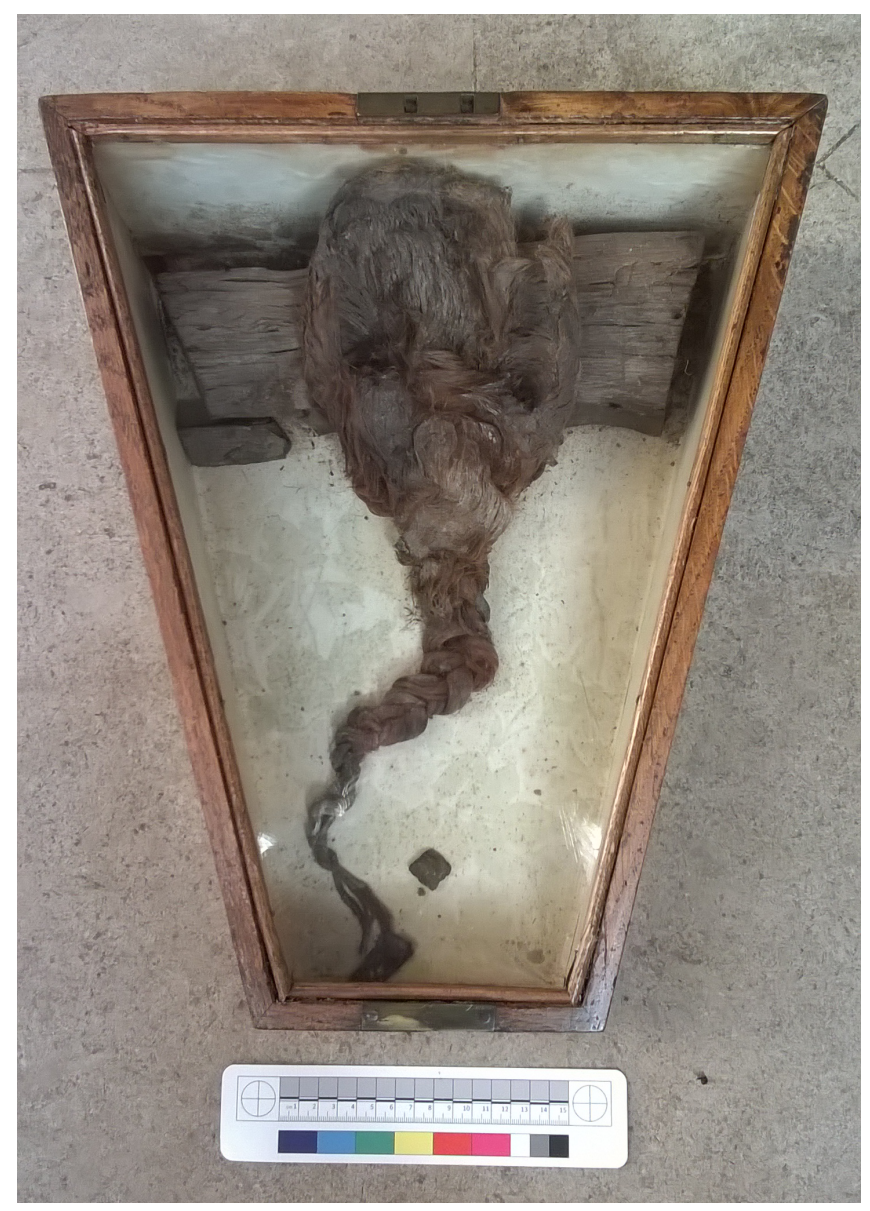

Figure 1: The head of hair and wooden pillow found inside a lead coffin excavated within the Abbey in 1839 (Photo: F. Green). The remains are presently displayed in a trapezoidal wood and plate glass box.

For this study of the head of hair, the box was examined to establish its construction and the best way to remove the glass to gain access to the contents. A layer of brown putty holding the plate-glass in place was removed, revealing an older layer of white putty. This allowed the oak beads and the nails securing them to be removed for further examination. A scalpel and knife were then used to remove the putty sealing the glass onto the box. Before lifting the glass, precautions were taken to avoid 
contamination of the hair with modern DNA, in case this is investigated in future. This included a full protective suit, face mask and double gloves. Sterilized laboratory scissors and tweezers were used to remove a 50mg sample of hair for radiocarbon dating and stable isotope analysis, in addition to a c.40mg sample of wood from the 'pillow'. In addition, a small sample of dark-coloured residue was removed from the right side of the head for analysis via GC/MS. This substance appears to be present on both sides of the head, forming a patchy coating over the hair surface (Figure 2). It may also be present towards the top of the head, though the position of the artifact relative to the box and fragility of the artefact precluded its manipulation for detailed examination of this area.

A more detailed report on the box opening is available from the site archive, along with a full Written Scheme of Investigation (WSI).

\begin{tabular}{|l|l|l|l|}
\hline Lab Ref. & Description & Analyses Performed & Technique \\
\hline P-39725 & Hair & $\begin{array}{l}\text { Isotopic measurement } \\
{ }^{14} \text { C Dating }\end{array}$ & $\begin{array}{l}\text { MS } \\
\text { AMS }\end{array}$ \\
\hline P-39726 & Wood & $\begin{array}{l}\text { Isotopic measurement } \\
{ }^{14} \text { C Dating }\end{array}$ & $\begin{array}{l}\text { MS } \\
\text { AMS }\end{array}$ \\
\hline RomRes & $\begin{array}{l}\text { Residue on Hair } \\
\text { (Right side) }\end{array}$ & Material characterisation & GC/MS \\
\hline
\end{tabular}

Table 1: Summary of samples taken and analyses performed in this investigation.
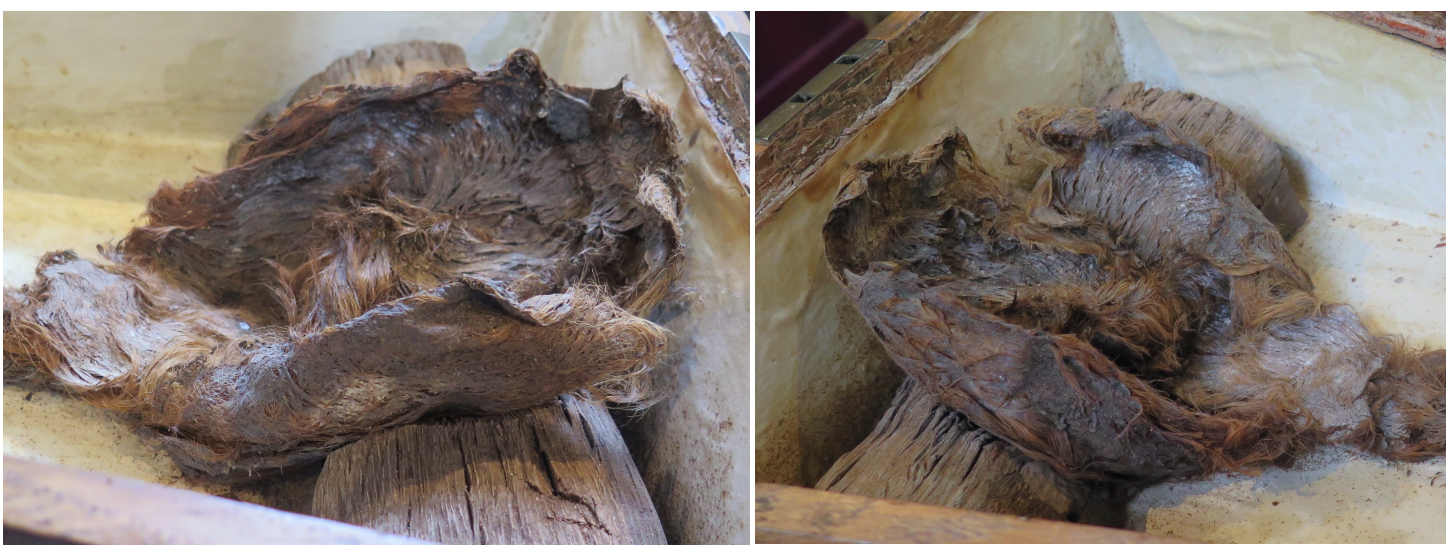

Figure 2: A view of the left (a) and right (b) sides of the head showing the superficial black substance that was sampled and identified as pine resin. For scale, see Figure 1 .

\subsubsection{Reference samples}

Two standards of Irish wood of known dendrochronological date were prepared and 215 radiocarbon dated in parallel to verify the accuracy of the results from the hair and wood samples of unknown age. 


\subsubsection{Solvents, reagents and standards}

The reagents used in radiocarbon pretreatment were $\mathrm{HCl}$ (Fluka TraceSELECT $>/ 30 \%$, Sigma-Aldrich, USA), $\mathrm{NaOH}$ (analytical reagent grade, Fisher Scientific, UK) Chloroform (99+\% for spectroscopy (stabilized), Acros Organics, Belgium), Acetone and Methanol (Distol, pesticide residue grade, Fisher Scientific, UK), Bleach (sodium chlorite $80 \%$ pure, unstabilized, Acros Organics, Belgium), Iron powder ( $<10 \mathrm{um}$ 99.9+\%, Aldrich Chemical Company, USA) and MilliQ ultrapure water (Merck 225 Millipore).

For the GC/MS analysis, methanol, n-hexane, potassium hydroxide, diethyl ether, hexadecane and tridecanoic acid were of analytical grade. BSTFA, containing 1\% trimethylchlorosilane, used for the trimethylsilylation derivatisation, was purchased in

$2301 \mathrm{~mL}$ ampoules and freshly opened for this analysis. All solvents, reagents and standards were purchased from Sigma Aldrich (USA) except hexane ordered from VWR International (UK) and ethanol from Fisher Scientific (UK).

\subsection{Methods}

\subsubsection{Radiocarbon Dating and Stable Isotope Measurements}

Two samples from Romsey Abbey, one of hair and one of wood, were analysed at the Oxford Radiocarbon Accelerator Unit (ORAU) in the Research Laboratory for 240 Archaeology and the History of Art (RLAHA).

Following a solvent wash to remove unidentified contaminants (e.g. glues), both samples were subjected to standard pretreatment methods at the ORAU (Brock et al., 2010). Because the base wash can rapidly dissolve hair samples, this step was

245 replaced with five 5-minute exposures to an ultrasonic bath containing fresh ultrapure water each time. Bleaching was performed for 5 minutes on the wood sample to isolate the carbohydrate (Brock et al., 2010).

Following freeze-drying, a 5mg sample was weighed into tin capsules for combustion 250 and compositional measurement in a Continuous Flow Isotope Ratio Mass Spectrometry (CF-IRMS) system. A portion of the pure $\mathrm{CO}_{2}$ gas produced through sample combustion was routed to a Europa Scientific Automated Nitrogen Carbon Analyser-Mass Spectrometer (ANCA-MS) system formed of a 20-20 IR-MS with a RoboPrep CHN sample converter unit operating in continuous flow mode using a $\mathrm{He}$

255 carrier gas. The remaining $\mathrm{CO}_{2}$ was captured in $10 \mathrm{ml}$ graphitization rigs containing hydrogen gas and $2-2.5 \mathrm{mg}$ powdered iron catalyst. Graphitisation was achieved by heating the sealed tube for 6 hours $\left(560^{\circ} \mathrm{C}\right)$, after which tube pressure was measured to detect leaks and possible contamination. The graphite sample was pressed into a 2mm-wide target for AMS measurement on the High Voltage Engineering Europa 260 (HVEE) system at the ORAU (Bronk Ramsey et al., 2004). 


\subsubsection{Gas Chromatography/Mass Spectrometry (GC/MS)}

The black sample ( $3 \mathrm{mg}$ ) was saponified and then the neutral and acidic fractions were extracted using hexane and diethylether, respectively (Figure 3). This protocol is based on the combined GC/MS analytical procedure developed for the characterization of organic materials in a paint microsample (Andreotti et al., 2006). The two fractions were subjected to derivatization with $20 \mu \mathrm{L}$ of $N, O$ bistrimethylsilyltrifluoroacetamide (containing 1\% trimethylchlorosilane), $50 \mu \mathrm{L}$ of hexane (solvent) and $5 \mu \mathrm{L}$ of tridecanoic acid solution (internal standard 1 ) at $70^{\circ} \mathrm{C}$ for 30 minutes. After derivatisation, the solution was transferred into to a GC-MS autosampler vial containing a micro-insert and $10 \mu \mathrm{L}$ of hexadecane solution (internal standard 2) was added. A blank sample was prepared following the same procedure.

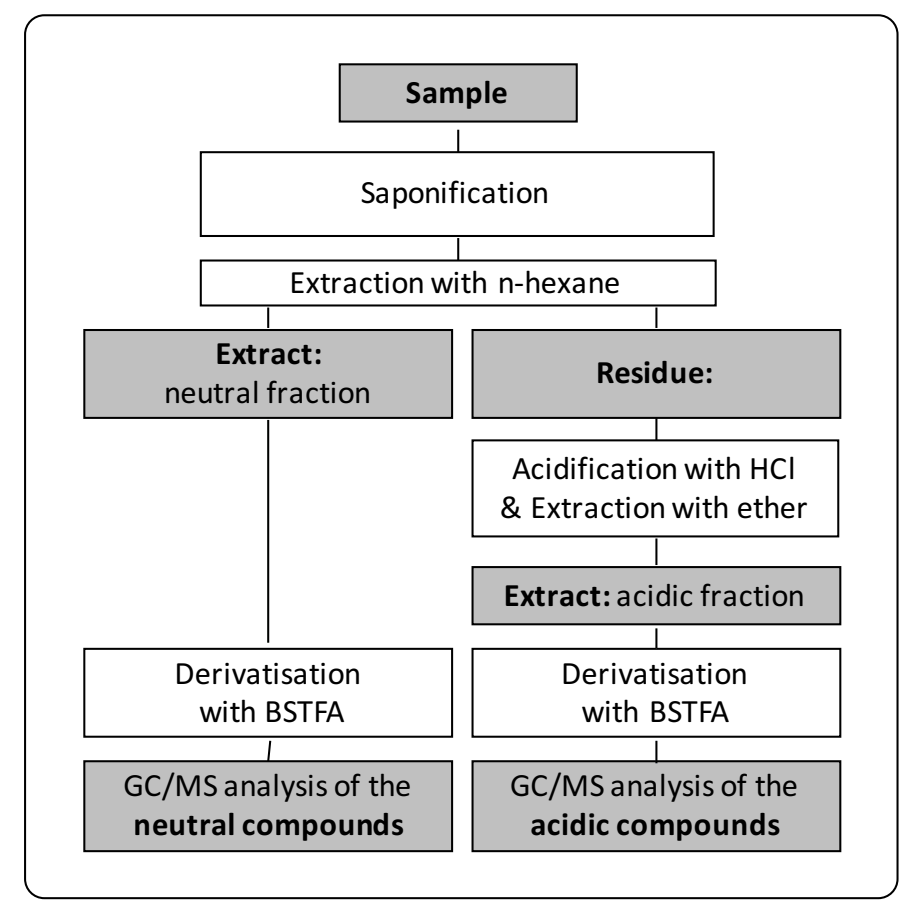

Figure 3: Analytical procedure for GC/MS analyses based on the combined GC/MS analytical procedure developed for the characterization of glycerolipid, waxy, resinous and proteinaceous materials in a paint microsample (Andreotti et al., 2006).

Samples were analyzed by GC/MS using an Agilent 7820A gas chromatograph equipped with a Restek Rxi-5ms column (30 m length x $0.25 \mathrm{~mm}$ ID x $0.25 \mu \mathrm{m}$ film 300 thickness, 5\% diphenyl / 95\% dimethylpolysiloxane stationary phase). The mass spectrometer was an Agilent 5975 quadrupole, operated in electron ionization mode $(70 \mathrm{eV}$ ) and the scan range was $m / z$ 50-650. The gas chromatograph conditions were as follows: inlet temperature $300^{\circ} \mathrm{C}$, flow rate $1.2 \mathrm{~mL} / \mathrm{min}$, transfer line temperature $280^{\circ} \mathrm{C}$. Helium was used as the carrier gas. The temperature program for the $\mathrm{GC}$ oven 305 was a $50^{\circ} \mathrm{C}$ hold for 2 minutes, $50-300^{\circ} \mathrm{C}$ at $10^{\circ} \mathrm{C} / \mathrm{min}$ with a 10 minute isothermal hold at $300^{\circ} \mathrm{C}$. Injections were made by an Agilent $7693 \mathrm{~A}$ autosampler and sample injection volume was $1 \mu \mathrm{L}$ in splitless mode. 


\section{Results and Discussion}

\subsection{Stable Isotope Analysis}

The stable isotopic measurements (Table 2) are expressed as delta $(\delta)$ values, expressed in parts per thousand, or 'per-mil' (\%), representing isotopic ratios relative to the international standards Vienna Pee Dee Belemnite (VPDB) for carbon and Ambient Inhalable Reservoir (AIR, or $\mathrm{N}_{2}$ ) for nitrogen. The elevated $\delta^{13} \mathrm{C}$ and $\delta^{15} \mathrm{~N}$ values obtained from the hair $(-19.5 \%$ and $+11.5 \%$ respectively) suggest the inclusion of marine protein in the diet, perhaps indicating an ecclesiastical diet. The archaeological context of a lead coffin adds further weight to the theory that these are the remains of a high-status individual.

\subsection{AMS Radiocarbon Dating}

Both samples yielded adequate material for radiocarbon measurement (Table 2). The Romsey hair sample produced a $\mathrm{C} / \mathrm{N}$ ratio of 3.7 , within the accepted quality range of 3.0-3.8 expected from modern hair keratin (O’Connell and Hedges, 1999).

\begin{tabular}{|c|c|c|c|c|c|c|c|c|}
\hline OxA- & Sample & $\begin{array}{c}\text { Sample } \\
(\mathbf{m g})\end{array}$ & $\begin{array}{c}\text { Yield } \\
(\mathbf{m g})\end{array}$ & $\begin{array}{c}{ }^{\mathbf{1 4}} \mathbf{C} \text { Yrs } \\
\mathbf{( B P )}\end{array}$ & $\begin{array}{c}\text { calBC/AD } \\
\mathbf{( 9 5 . 4 \% )}\end{array}$ & $\begin{array}{c}\boldsymbol{\delta}^{\mathbf{1 3}} \mathbf{C} \\
\mathbf{( \% o})\end{array}$ & $\begin{array}{c}\boldsymbol{\delta}^{\mathbf{1 5}} \mathbf{N} \\
(\mathbf{\% o})\end{array}$ & $\mathbf{C} / \mathbf{N}$ \\
\hline 32528 & Hair & 50.0 & $\begin{array}{c}40.62 \\
(81.2 \%)\end{array}$ & $1153 \pm 27$ & $895-1123 \mathrm{calAD} *$ & -19.5 & +11.5 & 3.7 \\
\hline 32529 & Wood & 39.1 & $\begin{array}{c}8.75 \\
(22.4 \%)\end{array}$ & $1084 \pm 27$ & $895-1016 \mathrm{calAD}$ & -24.0 & +7.8 & $-* *$ \\
\hline
\end{tabular}

Table 2: Results from the radiocarbon dating of the hair and wood.

* See below for a full explanation of the marine reservoir correction applied to 330 produce this date.

**The wood sample contained inadequate nitrogen for a $C / N$ ratio to be determined.

The measured radiocarbon 'date' is a value in radiocarbon $\left({ }^{14} \mathrm{C}\right)$ years BP (Before Present, conventionally AD 1950), calculated using a radiocarbon half-life of 5568 years. In order to obtain calendar dates (expressed as calBC/AD), these dates must be calibrated against international calibration curves produced using measurements of known-age samples, including tree rings. Calibration was undertaken against the IntCal13 calibration curve (Reimer et al., 2013), using OxCal v.4.2 (Bronk Ramsey, 2009). This resulted in calibrated dates of 776-970calAD (95.4\% probability) for the hair, and 895-1016calAD (95.4\% probability) for the wood (Figure 4). 


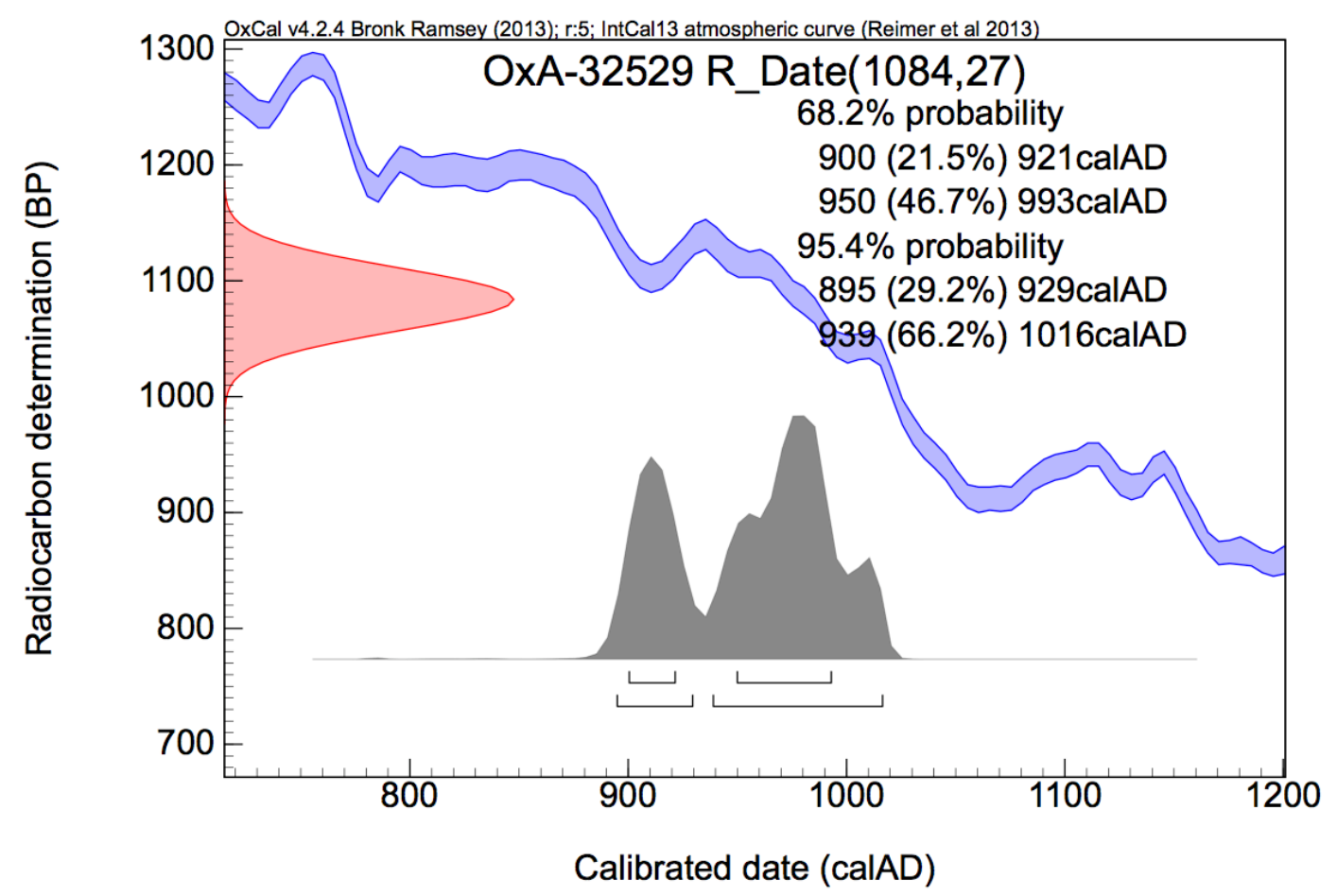

Figure 4: Calibrated date plot for the Romsey wood sample (OxA-32529, 1084 27 $B P)$.

\subsection{Marine Reservoir Correction}

The stable isotope measurements suggest the inclusion of marine protein in the diet of the deceased. Significant marine protein consumption can result in the incorporation of marine carbon into biological tissues, which is depleted in ${ }^{14} \mathrm{C}$ relative to atmospheric carbon. This can make samples incorporating significant quantities of marine protein appear erroneously old to radiocarbon dating. This may explain the apparently older date of the hair (776-970calAD) compared to the wood found in the same context (895-1016calAD).

In order to quantify the severity of this effect, it is possible to calculate the likely percentage of marine carbon in this individual's diet relative to terrestrial carbon, using a linear regression model with $\delta^{13} \mathrm{C}$ endpoints of $-21.0 \%$ ( $100 \%$ terrestrial) and $-12.5 \%$ (100\% marine) (following Arneborg et al., 1999). Because the model is

360 designed for use with isotopic values obtained from bone collagen, rather than hair, a correction was applied to estimate the likely bone collagen values of this individual, since no such material survives. Isotopic measurements of modern hair keratin and bone collagen within the same individuals have suggested that $\delta^{13} \mathrm{C}$ and $\delta^{15} \mathrm{~N}$ values in human bone collagen are elevated by an average of $+1.4 \%$ o for $\delta^{13} \mathrm{C}$ and $+0.86 \%$ o

365 for $\delta^{15} \mathrm{~N}$ compared to hair keratin (O'Connell et al., 2001). If these average enrichments are added to the isotopic results from the Romsey hair in order to estimate the bone collagen values of this individual, the values become $-18.1 \%$ and $+12.4 \%$ for $\delta^{13} \mathrm{C}$ and $\delta^{15} \mathrm{~N}$ respectively. A linear regression model (Arneborg et al., 
1999) can then be used to calculate a $34.1 \%$ marine carbon contribution to the tissues of the Romsey individual. It should be noted that this figure assumes that all ${ }^{13} \mathrm{C}$ enrichment in this individual is the result of marine carbon intake, rather than the consumption of ${ }^{13} \mathrm{C}$-enriched plants following the $\mathrm{C}_{4}$ (Hatch-Slack) photosynthetic pathway.

375 To take account of this inclusion of ${ }^{14} \mathrm{C}$-depleted marine carbon into the individual's tissues, a marine reservoir correction was applied during calibration of the date obtained for the Romsey hair sample. The date $1153 \pm 27$ BP was calibrated against mixed calibration curves of IntCal13 and Marine13 (Reimer et al., 2013), assuming a $34.1 \pm 10 \%$ marine carbon dietary component. The incorporation of an error of $\pm 10 \%$ follows Bayliss et al. (2004) and attempts to allow for the uncertainties associated with palaeodietary investigations using stable isotope analysis. To account for geographical variation in the severity of marine reservoir effects, a $\Delta R$ value $(-34 \pm 18)$ was calculated as the mean of the three available values recorded from coast of southern England and the English Channel (Harkness, 1983), using the 14CHRONO

385 Marine Reservoir Database. This results in a modelled date of 891-1117calAD (95.4\%); 963-1035calAD (68.2\%). However, an alternative $\Delta \mathrm{R}$ value for English coastal waters of $-5 \pm 40$ (Stuiver and Braziunas, 1993) produces a modelled date of 895-1123calAD (95.4\%); 965-1045calAD (68.2\%). The difference in the dates produced is negligible, even when the error of the $\%$ marine carbon figure is narrowed 390 from $\pm 10 \%$ to $\pm 5 \%$ (Table 3). To calculate a final date, the published value of $-5 \pm 40$ has been used (Stuiver and Braziunas, 1993), along with a more conservative $\pm 10 \%$ uncertainty associated with the calculated \% marine carbon value. This results in a calibrated date for the Romsey hair sample of 895-1123calAD (95.4\%); 9651045 calAD $(68.2 \%)$.

\begin{tabular}{|l|l|l|c|c|}
\hline${ }^{14} \mathbf{C}$ Yrs BP & $\begin{array}{c}\text { Marine C } \\
(\mathbf{\%})\end{array}$ & \multicolumn{1}{|c|}{$\mathbf{R}$} & $\begin{array}{c}\text { Modelled date } \\
\mathbf{( 9 5 . 4 \%} \text { probability })\end{array}$ & $\begin{array}{c}\text { Modelled date } \\
\mathbf{( 6 8 . 2 \%} \text { probability) }\end{array}$ \\
\hline $1153 \pm 27$ & $34.1 \pm 10$ & $-34 \pm 18$ & $891-1119$ calAD & $955-1034$ calAD \\
\hline $\mathbf{1 1 5 3} \pm \mathbf{2 7}$ & $\mathbf{3 4 . 1} \pm \mathbf{1 0}$ & $\mathbf{- 5} \pm \mathbf{4 0}$ & $\mathbf{8 9 5 - 1 1 2 3 c a l A D}$ & $\mathbf{9 6 5 - 1 0 4 5 c a l A D}$ \\
\hline $1153 \pm 27$ & $34.1 \pm 5$ & $-34 \pm 18$ & $903-1039$ calAD & $980-1025$ calAD \\
\hline $1153 \pm 27$ & $34.1 \pm 5$ & $-5 \pm 40$ & $902-1049$ calAD & $985-1017$ calAD \\
\hline
\end{tabular}

Table 3: Alternative marine-corrected date ranges are possible from the same radiocarbon measurement $(B P)$ by varying $\Delta R$ and the error margin of the percentage of marine to terrestrial dietary carbon. The chosen model is shown in 400 bold.

The accuracy of the marine correction applied here relies upon the validity of measured collagen-keratin offsets in $\delta^{13} \mathrm{C}$ in modern individuals (O'Connell et al., 405 2001) being applied to archaeological material, a $\delta^{13} \mathrm{C}$ linear regression model for assessing the proportion of dietary marine to terrestrial carbon (Arneborg et al., 1999), 
and $\Delta \mathrm{R}$ data for English Coastal Waters (Stuiver and Braziunas, 1993), in addition to the IntCal13 and Marine13 calibration curves (Reimer et al., 2013). As demonstrated above, slight variations in any of the above values and/or error margins are likely to alter the resulting calibrated date. As such, the marine-corrected hair date should be considered the most likely date range according to current knowledge. An additional important assumption of the marine correction is that the isotopic ratios measured in the hair sample are representative of marine protein obtained from British coastal waters, which may not necessarily be valid if this individual moved (or was moved) from a different region of Europe before burial at Romsey.

The marine-corrected date for the hair sample, 895-1123calAD (95.4\%), is consistent with the date obtained from the wooden 'pillow' also found in the grave, 8951016calAD (95.4\%) (Figure 5). The burial is certainly later than the Roman date 420 suggested by Berthon (1899), and is likely to be of mid to late Saxon date, although the hair could potentially date to a slightly later period after the Norman Conquest of 1066.

The radiocarbon date of the wood represents the felling date, and it is not known for 425 how long the wood might have been curated prior to deposition. It could have either been stored, or fulfilled some other purpose for many years before burial. Therefore, whilst the date for the wood is archaeologically useful, the hair itself is more firmly linked with the main event of interest, namely the death of the buried individual. It is perhaps significant that the 1-sigma $(68.2 \%$ certainty) date for the hair of 9651045 calAD suggests that this individual died between the mid-tenth to mid-eleventh century. Although this date is less certain, it would not be inconsistent with the date of 895-1016calAD (95.4\%) for the wooden pillow.

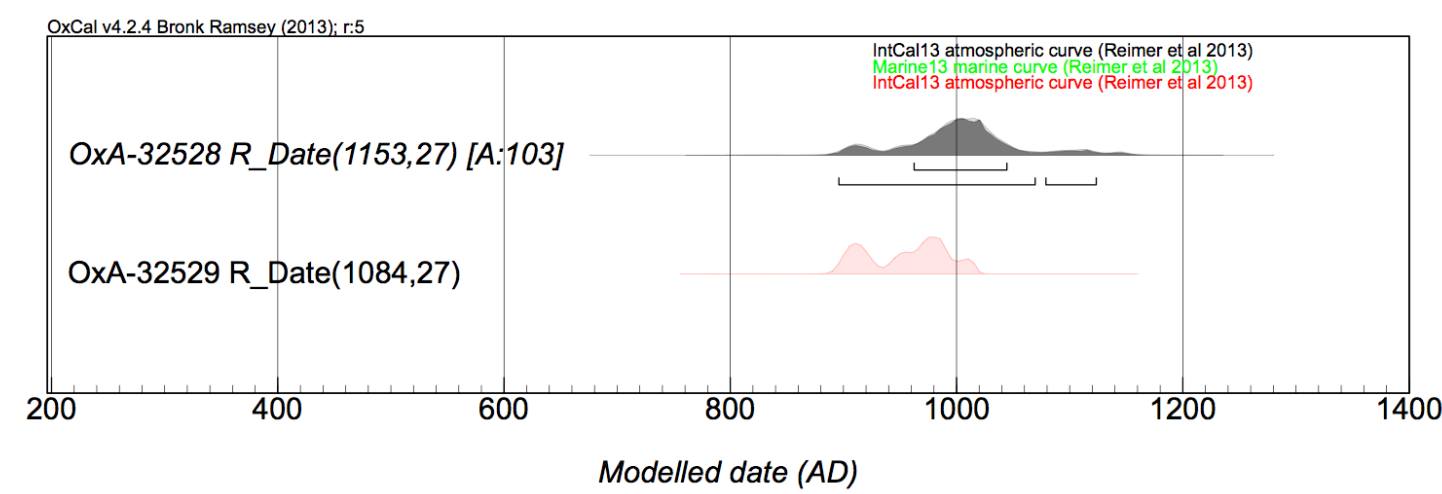

Figure 5: The combined IntCal13 and Marine13 calibrated date for the Romsey hair sample (OxA-32528) and the overlapping IntCall 3 calibrated date for the supporting wood (OxA-32529).

440 This new date for the 1839 grave (895-1123calAD) adds context to the development of the wider site of Romsey Abbey. The burial appears to have lain on northwest- 
southeast alignment, near the west end of the south nave aisle of the Norman abbey, though the precise location is unclear (Scott, 1996). Excavators at the Abbey have suggested that the grave may have pre-dated the late Saxon Abbey, the south transept or porticus of which may have been the hard 'concrete' layer that the sexton, Major, describes breaking through before reaching the coffin (Scott, 1996). It has been suggested that the burial may be contemporary with three confirmed graves on the same northwest-southeast alignment, which were excavated in 1975 at the north-west corner of the north transept of the late Saxon Abbey (Scott, 1996). A few metres to the east of these, two further possible graves were recorded on the same alignment (Scott, 1996). It should be noted, however, that the alignment of the hair burial may be misleading from a dating point of view as its position could have been affected by the later construction of the present Romanesque abbey, or even to accommodate the south porticus foundation of the previous stone church. Further chronometric dating might help to clarify the relationship of the 1839 discovery to these other burials.

\subsection{Residue analysis by Gas-Chromatography / Mass Spectrometry (GC/MS)}

The chromatogram corresponding to the acidic fraction extracted from the black sample after saponification presents a series of peaks corresponding to free linear saturated and unsaturated fatty acids with palmitic acid $\left(\mathrm{C}_{16: 0}\right)$, oleic acid $\left(\mathrm{C}_{18: 1}\right)$ and stearic acid $\left(\mathrm{C}_{18: 0}\right)$ as major peaks. These molecules are characteristic of degraded fatty substances from human or plant origin. They can also be associated with modern contamination. Because the artefact has been manipulated several times since it was discovered, no conclusion can be drawn based on these molecules.

However, based on their mass spectra, didehydroabietic acid, dehydroabietic acid and 7-oxo-dehydroabietic acid were also identified (Figure 6). These diterpenoid molecules with an abietane skeleton are characteristic components of resins that exude from species of the Pinaceae family and are considered as markers for pine resin in aged materials (Eerkens, 2002, Colombini et al., 2003). The dehydroabietic acid methyl ester is not a marker of pine resin but was likely formed during the saponification. Based on the molecular identification of these abietane molecules, it is possible to conclude that this resin was applied to the hair during life and/or as part of the funerary process.

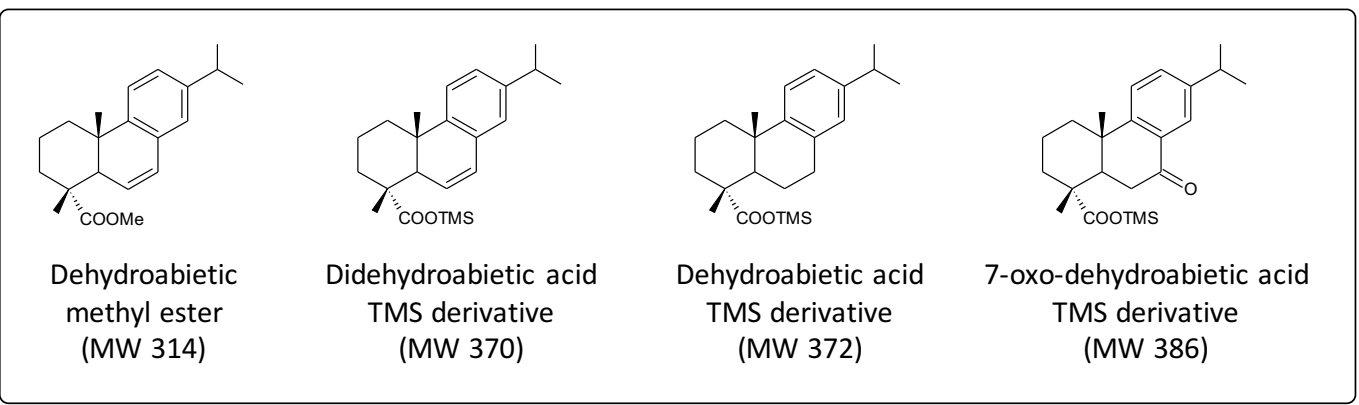

Figure 6: Diterpenoid markers characteristic of resins from the Pinaceae family identified by GC/MS in the black residue found on the hair. 


\subsection{Identity of the deceased}

It is impossible at present to verify the identity of the individual buried at Romsey. The lead and wooden coffins in which the remains were found would suggest that this was an individual of significant status and, most likely, wealth. The significant marine component in the diet, suggested by the isotopic results, could be indicative of an ecclesiastical diet. The new radiocarbon dates assign the burial to a significant period in the history of the Abbey, indicating that this individual could conceivably have lived at the time of the foundation of the institution in the early tenth century, or soon after. Previous suggestions as to the identity of these remains have included St Elfleda, thought to have been the daughter of the Abbey's founder, King Edward the

490 Elder (r. 901-924 AD) and granddaughter of King Alfred the Great (r. 868-899 AD), and the $10^{\text {th }}$ century abbesses of Romsey St Merwenna and St Ethelflaeda. Another possibility is Edmund Atheling (c.1016-1054 AD). The date range produced here is not adequately precise to rule out any of these claims. We stress, however, that it is highly unlikely that the identity of this individual can ever be established with any certainty.

\section{Conclusions}

Radiocarbon dating has shown that the preserved hair in Romsey Abbey is likely to date from the end of the ninth century to the early twelfth century, whilst the wood used to support it in the grave was felled at some point between the end of the ninth century and the early eleventh century. This is consistent with previous estimates of the grave as mid-late Saxon (c.650-1066), though the possible date range also extends several decades after the Conquest, to the early twelfth century. The stable isotopic measurements indicate the potential inclusion of fish in the diet, perhaps supporting

505 the theory that this may have been an ecclesiastical individual. The identification of Pinacea resin on the surface of the hair suggests deliberate application of this substance during life and/or the funerary process.

\section{6. Acknowledgements}

We thank the Revd. Canon Tim Sledge, Vicar of Romsey, along with the Wardens and staff of Romsey Abbey for granting permission to study the hair and remove samples for testing. We are also grateful for the assistance of the Winchester Diocesan Advisory Committee for the Care of Churches and Diocesan Chancellor His Hon.

515 Judge Christopher Clark, QC. The advice and assistance of Dr Simon Mays (Human Skeletal Biologist, Historic England), Dr Michael Heyworth (Director, Council for British Archaeology) and Dr Joseph Elders (Major Projects Officer, Church of England Cathedral and Church Buildings Division) is also gratefully acknowledged.

520 The scientific work was funded by the Research Laboratory for Archaeology and the History of Art (RLAHA) and the Oxford Radiocarbon Accelerator Unit (ORAU) at the University of Oxford, and we thank Professor Thomas Higham and other ORAU staff for assistance and advice on radiocarbon dating and stable isotope analysis. We 
are also grateful for the advice and assistance of Dr Georges Kazan of the Institute of 525 Archaeology, University of Oxford and Dr Daniel Miles of the Oxford Dendrochronology Laboratory. 


\section{References}

530 Andreotti, A., Bonaduce, I., Colombini, M. P., Gautler, G., Modugno, F. and Ribechini, E. (2006) Combined GC/MS Analytical Procedure for the Characterization of Glycerolipid, Waxy, Resinous, and Proteinaceous Materials in a Unique Paint Microsample. Analytical Chemistry 78(13): 4490-4500.

Arneborg, J., Heinemeier, J., Lynnerup, N., Nielsen, H. L., Rud, N. and Sveinbjörnsdóttir, A. E. (1999) 535 Change of Diet of the Greenland Vikings Determined from Stable Isotope Analysis and 14C Dating of their Bones. Radiocarbon 41(2): 157-168.

Bayliss, A., Marshall, P. and Sidell, J. (2004) A Puzzling Body from the River Thames in London. Radiocarbon 46(1): 285-291.

Berthon, E. L. (1899) A Retrospect of Eight Decades. London: George Bell and Sons.

Bocherens, H. and Drucker, D. (2003) Trophic Level Isotopic Enrichment of Carbon and Nitrogen in Bone Collagen: Case Studies from Recent and Ancient Terrestrial Ecosystems. International Journal of 545 Osteoarchaeology 13: 46-53.

Brock, F., Higham, T., Ditchfield, P. and Bronk Ramsey, C. (2010) Current pretreatment methods for AMS radiocarbon dating at the Oxford Radiocarbon Accelerator Unit (ORAU). Radiocarbon 52(1): $103-112$.

Bronk Ramsey, C. (2009) Bayesian Analysis of Radiocarbon Dates. Radiocarbon 51, 1, 337-360.

Bronk Ramsey, C., Higham, T. and Leach, P. (2004) Towards High-Precision AMS: Progress and Limitations. Radiocarbon 46(1): 17-24.

Coldicott, D. K. (1989) Hampshire Nunneries. Chichester: Phillimore \& Co..

Collier, C. (1990) Romsey Minster in Saxon Times. Proceedings of the Hampshire Field Club Archaeological Society 46: 41-52.

Colombini, M. P., Giachi, G., Modugno, F., Pallecchi, P. and Ribechini, E. (2003) The characterization of paints and waterproofing materials from the shipwrecks found at the archaeological site of the Etruscan and Roman harbour of Pisa (Italy). Archaeometry 45(4): 659-674.

565 Eerkens, J. (2002). The Preservation and Identification of Piñon Resins by GC-MS in Pottery from the Western Great Basin. Archaeometry 44(1): 95-105.

Hallett, E. (2015) Romsey Abbey: The First 1100 Years. Romsey Abbey Parochial Church Council.

570 Harkness, D. D. (1983) The extent of the natural 14C deficiency in the coastal environment of the United Kingdom. Journal of the European Study Group on Physical, Chemical and Mathematical Techniques Applied to Archaeology PACT 8 (IV.9): 351-364.

Hedges, R. E. M. \& Reynard, L. M. (2007) Nitrogen isotopes and the trophic level of humans in archaeology. Journal of Archaeological Science 34: 1240-1251.

Lee-Thorp, J. A. (2008) On Isotopes and Old Bones. Archaeometry 50(6): 925-950.

Major, J. (1862) Copy of notes held at the Vicarage, made by J Major, 1862. Transcribed with original spelling by P. Genge in 1986. 
O’Connell, T. C. \& Hedges, R. E. M. (1999). Investigations into the effect of diet on modern human hair isotopic values. American Journal of Physical Anthropology 108, 409-425.

585 O’Connell, T. C., Hedges, R. E. M., Healey, M. A. \& Simpson, A. H. R. W. (2001) Isotopic Comparison of Hair, Nail and Bone: Modern Analyses. Journal of Archaeological Science 28, 12471255 .

O’Leary, M. H. (1988) Carbon Isotopes in Photosynthesis. BioScience 38(5): 328-336.

Reimer, P. J., Bard, E., Bayliss, A., Beck, J. W., Blackwell, P. G., Bronk Ramsey, C. B., Buck, C. E., Cheng, H., Edwards, R. L., Friedrich, M., Grootes, P. M., Guilderson, T. P., Haflidason, H., Hajdas, I., Hatté, C., Heaton, T. J., Hoffmann, D. L., Hogg, A. G., Hughen, K. A., Kaiser, K. F., Kromer, B., Manning, S. W., Niu, M., Reimer, R. W., Richards, D. A., Scott, E. M., Southon, J. R., Staff, R. A., 595 Turney, C. S. M. and van der Plicht, J., 2013. IntCal13 and Marine13 Radiocarbon Age Calibration Curves 0-50,000 Years Cal BP. Radiocarbon, 55(4): 1869-1887.

Scott, I. R. (1996) Romsey Abbey: Report on the Excavations 1973-1991 (Hampshire Field Club Monograph 8). Stroud: Sutton Publishing Limited (for the Hampshire Field Club and Archaeological 600 Society and Test Valley Archaeological Trust).

Stuiver, M. and Braziunas, T. F. (1993) Modeling Atmospheric ${ }^{14} \mathrm{C}$ Influences and ${ }^{14} \mathrm{C}$ Ages of Marine Samples to 10,000 BC. Radiocarbon, 35(1): 137-189.

605 The Gentleman's Magazine (1840) Letter to Mr Urban, Editor, signed 'J. G. N.', August 1840: 138141.

Walker, J. (2013) Romsey Abbey Through the Centuries (Revised Edition). Romsey Abbey Parochial Church Council. 